Original article

\title{
New record of ornithopod dinosaur from the Plottier Formation (Upper Cretaceous), Patagonia, Argentina
}

\section{Nouvelle occurrence de dinosaure ornithopode de la Formation Plottier (Crétacé Supérieur), Patagonie, Argentine}

\author{
Penélope Cruzado-Caballero ${ }^{\mathrm{a}, *}$, Leonardo S. Filippi ${ }^{\mathrm{b}}$, Ariel H. Méndez ${ }^{\mathrm{a}}$, \\ Alberto C. Garrido ${ }^{\mathrm{c}, \mathrm{d}}$, Rubén D. Juárez Valieri ${ }^{\mathrm{e}}$ \\ a CONICET, Instituto de Investigación en Paleobiología y Geología (CONICET-UNRN), Avenida Roca 1242, General Roca, Río Negro, Argentina \\ b Museo Municipal Argentino Urquiza, Jujuy y Chaco s/n, Rincón de los Sauces, Neuquén, Argentina \\ c Museo Provincial de Ciencias Naturales “Prof. Dr. Juan Olsacher”, Dirección Provincial de Minería, Etcheluz y Ejército Argentino, Zapala, Neuquén, \\ Argentina \\ d Departamento Geología y Petróleo, Facultad de Ingeniería, Universidad Nacional del Comahue, Neuquén, Buenos Aires 1400, Argentina \\ e Secretaría de Cultura de la Provincia de Río Negro, General Roca, Río Negro, Argentina
}

\section{A R T I C L E I N F O}

\section{Article history:}

Received 20 January 2016

Accepted 19 February 2016

Available online 24 May 2016

\section{Keywords:}

Dinosauria

Ornithopoda

Cretaceous

Coniacian-Santonian

Argentina

\begin{abstract}
A B S T R A C T
Ornithopods are the least known dinosaurs within the Upper Cretaceous record of Argentina. For this reason every new record is very important to know their evolution in South America. Here, we describe a new remain of an indeterminate ornithopod recovered in the Petrobrasaurus quarry of the Puesto Hernández area, northeastern Neuquén province (Argentina), late Coniacian-early Santonian in age. MAU-Pv-PH458 is the northernmost bone record of an ornithopod in Argentina. This is a fragmentary neural arch from the middle section of the dorsal series of similar size to Macrogryphosaurus gondwanicus. MAU-Pv-PH-458 has typical ornithopod characters such as a lateromedial narrow neural spine and transverse processes dorsoposteriorly to posteriorly oriented. It shares with Macrogryphosaurus the presence of a deep channel between the bases of the postzygapophysis, which is a continuation of the channel that separates the postzygapophyses in posterior view. MAU-Pv-PH-458 increases the ornithopod record from the Plottier Formation.
\end{abstract}

(C) 2016 Elsevier Masson SAS. All rights reserved.

\section{R É S U M É}

La présence de dinosaures ornithopodes dans le Crétacé supérieur est encore peu documentée en Argentine. Chaque nouvelle découverte est très importante pour connaître l'évolution de ce groupe en Amérique du Sud. Nous décrivons ici de nouveaux restes fossiles d'un ornithopode indéterminé trouvés dans la carrière à Petrobrasaurus de la localité Puesto Hernández, dans le Coniacien supérieur-Santonien inférieur de la partie Nord-Est de la province de Neuquén (Argentine). MAU-Pv-PH-458 est le matériel ostéologique d'ornithopode découvert le plus au Nord en Argentine. Il s'agit d'un arc neural fragmentaire provenant de la partie moyenne de la série vertébrale dorsale et dont la taille est similaire à celle de Macrogryphosaurus gondwanicus. MAU-Pv-PH-458 montre des caractères typiques d'ornithopode, tels qu'une épine neurale latéro-médialement étroite, des processus transverses orientés dorso-postérieurement à postérieurement, entre autres. Il partage avec Macrogryphosaurus la présence d'un profond sillon entre la base des postzygapophyses, qui est la continuité du sillon séparant les postzygapophyses en vue postérieure. MAU-Pv-PH-458 augmente la liste des découvertes d'ornithopodes de la Formation Plottier.

(C) 2016 Elsevier Masson SAS. Tous droits réservés.

\footnotetext{
* Corresponding author.

E-mail addresses: pccaballero@unrn.edu.ar (P. Cruzado-Caballero), lsfilippi@gmail.com (L.S. Filippi), arielhmendez@yahoo.com.ar (A.H. Méndez), albertocarlosgarrido@gmail.com.ar (A.C. Garrido), rubenjuarez@gmail.com (R.D. Juárez Valieri).
} 


\section{Introduction}

The fossil record of Ornithopoda from the Upper Cretaceous of Argentina plus Antarctica is sparse at a low taxonomic level compared with that of other dinosaurs (Coria and Cambiaso, 2007; Rozadilla et al., 2016). Seven different species are identified: Gasparinisaura cincosaltensis Coria and Salgado, 1996b, Notohypsilophodon comodorensis Martínez, 1998, Anabisetia saldiviai Coria and Calvo, 2002, Talenkauen santacrucensis Novas et al., 2004, Macrogryphosaurus gondwanicus Calvo et al., 2007, Trinisaura santamartaensis Coria et al., 2013, and Morrosaurus antarcticus Rozadilla et al., 2016 (see Table 1), and abundant fragmentary remains diagnosable only to high taxonomic level. The fragmentary character of these remains, the shortage of anatomic elements similar or diagnostic complicates the comparison between taxa and, therefore, studies on paleobiodiversity.

We present a fragmentary dorsal neural arch of an ornithopod (MAU-Pv-PH-458) from the Puesto Hernández fossil site (Filippi et al., 2011; Fig. 1). In this area, there are exposed outcrops belonging to the Plottier Formation (late Coniacian-early Santonian) of the Río Neuquén Subgroup. In this quarry, the titanosaur sauropod Petrobrasaurus puestohernandezi Filippi et al., 2011, and two different types of theropod teeth (Canudo et al., 2009; Filippi et al., 2011) were previously described. The record of dinosaur remains from the Plottier Formation is scarce, being composed from the remains previously mentioned plus several remains from other localities of the Neuquén and Río Negro provinces. In the Neuquén province, dinosaur bones have been found in the Aguada del Caño locality (the huge titanosaur "Antarctosaurus giganteus", undetermined titanosaur and theropod dinosaurs; Von Huene, 1929) and in the Narambuena site (an indeterminate Aeolosaurini, Filippi et al., 2013). In the Río Negro province, vestiges of dinosaurs have been localized in the El Anfiteatro area: several fragmentary remains of titanosaurs, carcharodontosaurids, unenlagiids, indeterminate coelurosaurs and theropods, and a pedal ungueal phalanx of an indeterminate ornithopod, the only other bone of an

Table 1

Cretaceous ornithopod record from Argentina.

Occurrences d'ornithopodes crétacés d'Argentine.

\begin{tabular}{|c|c|c|c|c|c|}
\hline Locality & Taxon & Current status & Age & Stratigraphic unit & References \\
\hline \multicolumn{6}{|l|}{ Río Negro province } \\
\hline Cinco saltos & $\begin{array}{l}\text { Gasparinisaura } \\
\text { cincosaltensis }\end{array}$ & $\begin{array}{l}\text { Gasparinisaura } \\
\text { cincosaltensis }\end{array}$ & $\begin{array}{l}\text { Santonian-early } \\
\text { Campanian }\end{array}$ & $\begin{array}{l}\text { Anacleto Fm., Río Colorado } \\
\text { subgroup, Neuquén Group }\end{array}$ & $\begin{array}{l}\text { Coria and Salgado (1996b) } \\
\text { Salgado et al. (1997) } \\
\text { Coria (1999) } \\
\text { Dingus et al. (2000) } \\
\text { Coria and Cambiaso (2007) }\end{array}$ \\
\hline El Anfiteatro & Ornithopoda indet. & Ornithopoda indet. & $\begin{array}{l}\text { Late Coniacian-late } \\
\text { Santonian }\end{array}$ & $\begin{array}{l}\text { Plottier Fm., Río Neuquén } \\
\text { subgroup, Neuquén Group }\end{array}$ & Salgado et al. (2009) \\
\hline \multicolumn{6}{|l|}{ Neuquén province } \\
\hline Cerro Bayo Mesa & Anabisetia saldiviai & Anabisetia saldivia & Turonian & $\begin{array}{l}\text { Cerro Lisandro Fm., Río } \\
\text { Neuquén subgroup, } \\
\text { Neuquén Group }\end{array}$ & Coria and Calvo (2002) \\
\hline $\begin{array}{l}\text { Southwestern coast } \\
\text { of Mari Menuco } \\
\text { lake }\end{array}$ & $\begin{array}{l}\text { Macrogryphosaurus } \\
\text { gondwanicus }\end{array}$ & $\begin{array}{l}\text { Macrogryphosaurus } \\
\text { gondwanicus }\end{array}$ & Middle-late Coniacian & $\begin{array}{l}\text { Sierra Barrosa Fm., Río } \\
\text { Neuquén subgroup, } \\
\text { Neuquén Group }\end{array}$ & Calvo et al. (2007) \\
\hline Bandera Hill & Iguanodontia indet. & Iguanodontia indet. & Coniacian & $\begin{array}{l}\text { Portezuelo Fm., Río } \\
\text { Neuquén Subgroup, } \\
\text { Neuquén Group }\end{array}$ & Coria and Cambiaso (2007) \\
\hline Plaza Huincul & Iguanodontia indet. & Iguanodontia indet. & Cenomanian & $\begin{array}{l}\text { Huincul Fm. (ACG pers. } \\
\text { obs.), Río Limay Subgroup, } \\
\text { Neuquén Group }\end{array}$ & $\begin{array}{l}\text { Coria et al. (2004) } \\
\text { Coria et al. (2007) }\end{array}$ \\
\hline $\begin{array}{l}\text { Northern coast of Los } \\
\text { Barreales lake }\end{array}$ & Iguanodontia indet. & Iguanodontia indet. & Coniacian & $\begin{array}{l}\text { Portezuelo Fm., Río } \\
\text { Neuquén subgroup, } \\
\text { Neuquén Group }\end{array}$ & $\begin{array}{l}\text { Porfiri and Calvo (2002) } \\
\text { Calvo and Porfiri (2003) }\end{array}$ \\
\hline Agrio del Medio & Ornithopoda indet. & Ornithopoda indet. & $\begin{array}{l}\text { Late } \\
\text { Cenomanian-Turonian }\end{array}$ & $\begin{array}{l}\text { Huincul Fm., Río Limay } \\
\text { subgroup, Neuquén Group }\end{array}$ & Canudo et al. (2013) \\
\hline $\begin{array}{l}\text { Puesto Hernández } \\
\text { quarry, Rincón de } \\
\text { los Sauces }\end{array}$ & Ornithopoda indet. & Ornithopoda indet. & $\begin{array}{l}\text { Late Coniacian-late } \\
\text { Santonian }\end{array}$ & $\begin{array}{l}\text { Plottier Fm., Río Neuquén } \\
\text { subgroup, Neuquén Group }\end{array}$ & This paper \\
\hline \multicolumn{6}{|l|}{ Chubut province } \\
\hline $\begin{array}{l}\text { Neighboring of Buen } \\
\text { Pasto, Chubut } \\
\text { province }\end{array}$ & $\begin{array}{l}\text { Notohypsilophodon } \\
\text { comodorensis }\end{array}$ & $\begin{array}{l}\text { Notohypsilophodon } \\
\text { comodorensis }\end{array}$ & $\begin{array}{l}\text { Middle } \\
\text { Cenomanian-Turonian }\end{array}$ & $\begin{array}{l}\text { Bajo Barreal Fm., Chubut } \\
\text { Group }\end{array}$ & $\begin{array}{l}\text { Martínez (1998) } \\
\text { Lamanna et al. (2003) } \\
\text { Ibiricu et al. (2014) }\end{array}$ \\
\hline $\begin{array}{l}\text { Southeastern of the } \\
\text { Colhué Huapi lake }\end{array}$ & Ornithopoda indet. & Ornithopoda indet. & $\begin{array}{l}\text { Middle } \\
\text { Cenomanian-Turonian }\end{array}$ & $\begin{array}{l}\text { Bajo Barreal Fm., Upper } \\
\text { Member }\end{array}$ & Ibiricu et al. (2010) \\
\hline \multicolumn{6}{|l|}{ Santa Cruz province } \\
\hline $\begin{array}{l}\text { Los Hornos Hill, } \\
\text { Argentino lake }\end{array}$ & $\begin{array}{l}\text { Talenkauen } \\
\text { santacrucensis }\end{array}$ & $\begin{array}{l}\text { Talenkauen } \\
\text { santacrucensis }\end{array}$ & Maastrichtian & Pari Aike Fm. & Novas et al. (2004) \\
\hline Pair-Aike & $\begin{array}{l}\text { "Loncosaurus } \\
\text { argentinus" }\end{array}$ & Ornithopoda indet. & Cenomanian-Santonian & Mata Amarilla Fm. & $\begin{array}{l}\text { Ameghino (1899) } \\
\text { Molnar (1980) } \\
\text { Coria and Salgado (1996a) } \\
\text { Coria and Cambiaso (2007) }\end{array}$ \\
\hline \multicolumn{6}{|l|}{ Antartica } \\
\hline $\begin{array}{l}\text { Santa Marta Cove, } \\
\text { James Ross Island }\end{array}$ & $\begin{array}{l}\text { Trinisaura } \\
\text { santamartaensis }\end{array}$ & $\begin{array}{l}\text { Trinisaura } \\
\text { santamartaensis }\end{array}$ & Upper Campanian & Snow Hill Island Fm. & Coria et al. (2013) \\
\hline $\begin{array}{l}\text { El Morro Peninsula, } \\
\text { James Ross Island }\end{array}$ & Morrosaurus antarcticus & Morrosaurus antarcticus & Maastrichtian & López de Bertodano Fm. & Rozadilla et al. (2016) \\
\hline Vega Island & $\begin{array}{l}\text { A basla euornithopoda } \\
\text { indet. }\end{array}$ & $\begin{array}{l}\text { A basal euornithopoda } \\
\text { indet. }\end{array}$ & Maastrichtian & López de Bertodano Fm. & $\begin{array}{l}\text { Hooker et al. (1991) } \\
\text { Coria et al. (2013) }\end{array}$ \\
\hline $\begin{array}{l}\text { Santa Marta Cove, } \\
\text { James Ross Island, } \\
\text { Antarctica }\end{array}$ & Ornithopoda indet. & Ornithopoda indet. & Upper Campanian & Snow Hill Island Fm. & $\begin{array}{l}\text { Coria et al. (2007) } \\
\text { Coria et al. (2013) }\end{array}$ \\
\hline
\end{tabular}




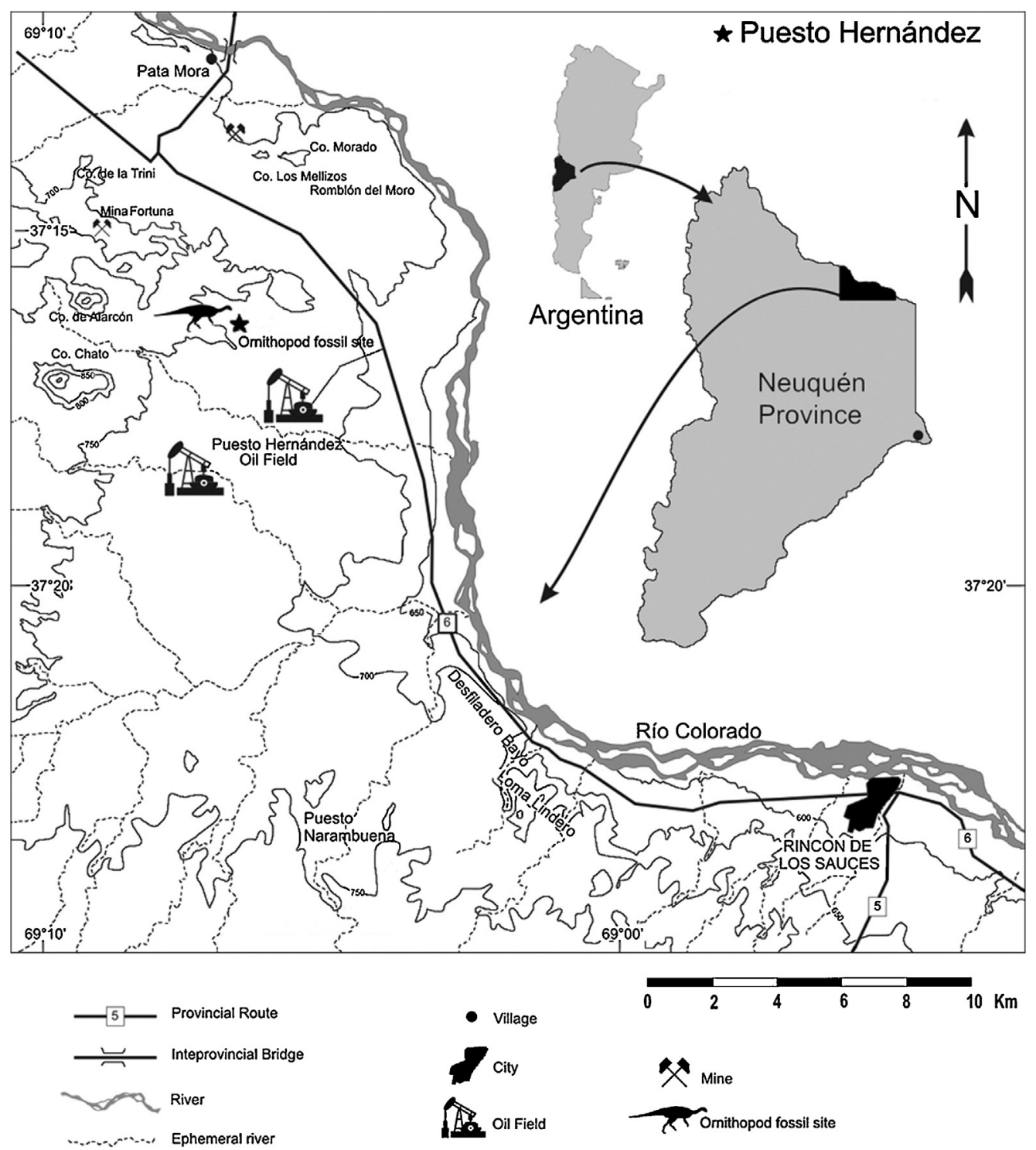

Fig. 1. Location map of Puesto Hernández (Neuquén, Patagonia, Argentina).

Carte de localisation de Puesto Hernández (Neuquén, Patagonie, Argentine).

indeterminate ornithopod from the Plottier Formation, (Salgado et al., 2009). In this context, the new material MAU-Pv-PH-458, although very fragmentary, is important, because it is the northernmost record of a South American ornithopod and the second bone in the Plottier Formation from the Neuquén province.

The main goals of the present paper are:

- to describe the first dorsal neural arch of an ornithopod from the Plottier Formation for the Neuquén province;

- to compare the osteology with the other Argentinean plus Antarctic ones;

- to provide new insights into the paleobiodiversity and paleobiogeography of the ornithopods in Argentina.

Insitutional abbreviations: MAU-Pv-PH: Museo Argentino Urquiza - Paleontología de Vertebrados - Puesto Hernández.

\section{Geological setting}

Specimen MAU-PV-PH-458 was recovered from the lower part of the Plottier Formation (Río Neuquén Subgroup, Neuquén Group), with an estimated age situated into later Coniacian-early Santonian (Garrido, 2010). Although this unit is not exposed their base at the study area, field observations corroborated that its lower limit would be located no more than $12 \mathrm{~m}$ below the bottom of the profile represented on Fig. 2.

The deposits of the fossil site have been characterized by Filippi et al. (2011) as fluvial deposits linked to sandy braided channel systems. The fossil-bearing levels comprise a $2.5 \mathrm{~m}$ thick fill channel deposits, composed mainly by quarzolithic, coarse to medium-grained sandstones with develop of sets of planar cross-stratification and low angle cross-stratification. Laterally, horizontal stratification is also developed. The identification in this level of downstream-accretion macroforms (sensu Miall, 1996), allows to assign these deposits to longitudinal or mid-channel sandy bars.

The base of the body exhibits a strong erosive contact, followed by small lens (minor $10 \mathrm{~cm}$ thick) formed by coarse lithic granules and abundant muddy intraclasts. Precisely, one of these lenses yields the piece under study, such deposits were linked to scour and fill deposits (lithofacies Ss, sensu Miall, 1996). Along the outcrop, this type of deposits yields abundant teeth and isolated small 


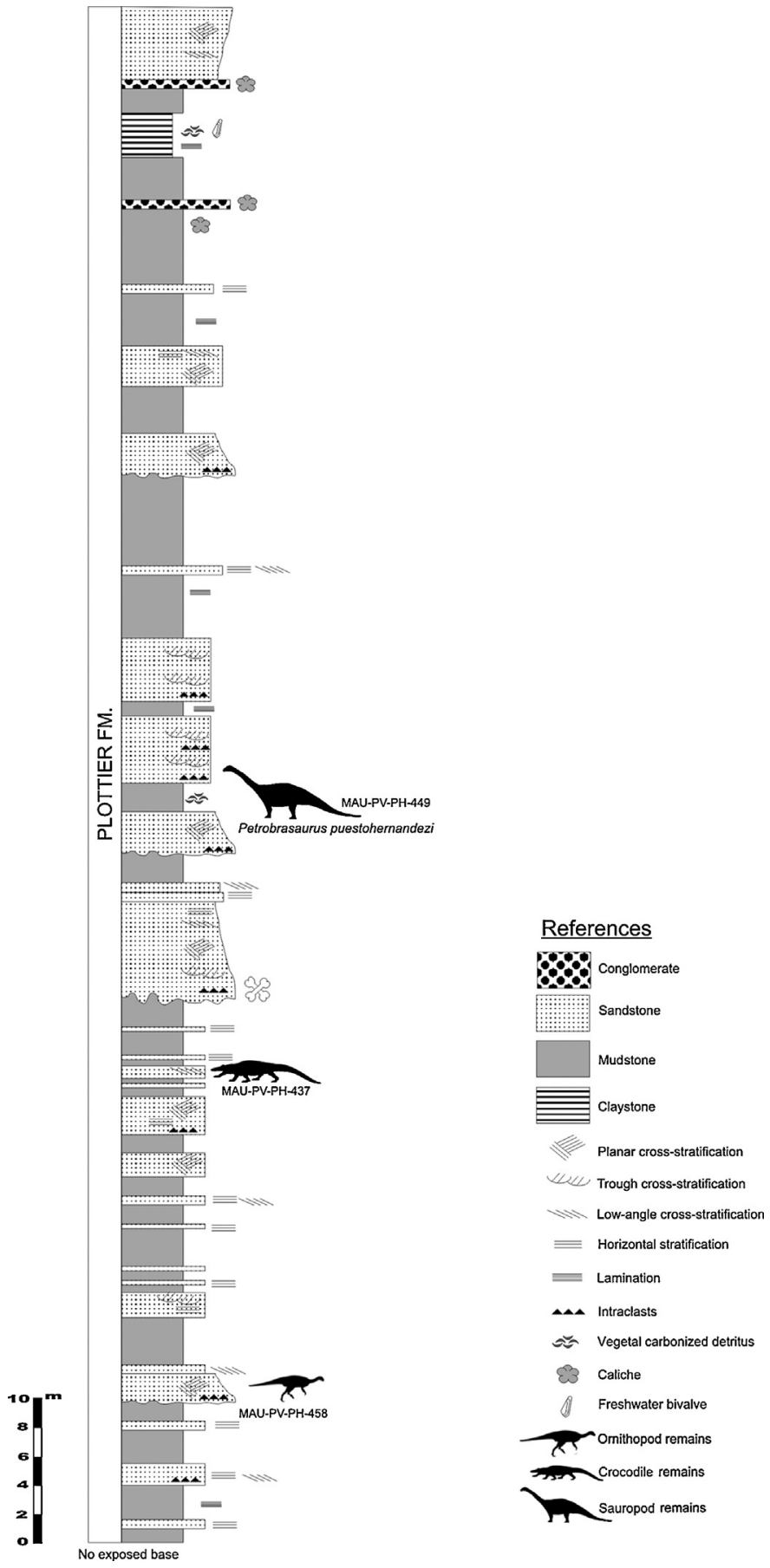

Fig. 2. Lithostratigraphic section of the Plottier Formation in Puesto Hernández site. Coupe lithostratigraphique de la Formation Plottier à la localité Puesto Hernández.

bone pieces, besides exhibiting strong abrasion, which suggest a prolonged action transport and subsequent deposition as bottom, channel-lag deposits.

\section{Systematic paleontology}

Dinosauria Owen, 1842

Ornithischia Seeley, 1887

Ornithopoda Marsh, 1881

\section{Ornithopoda indet.}

Material: a partial dorsal neural arch (MAU-Pv-PH-458).
Horizon and locality: late Coniacian-early Santonian, Plottier Formation (Río Neuquén Subgroup, Neuquén Group, Neuquén Basin; Garrido, 2010). Puesto Hernández Oil field area, 25 km northwest of the Rincón de los Sauces city, Neuquén province, Patagonia, Argentina.

\section{Description and comparison}

MAU-Pv-PH-458 is a fragmentary mid-dorsal neural arch (Fig. 3A-C). This specimen displays typical characters of Ornithopoda, such as a lateromedially narrow neural spine, dorsoposteriorly to posteriorly addressed transverse process, articular surface of the prezygapophyses mediolaterally inclined, and articular surfaces of the postzygapophyses laterally inclined (Norman et al., 2004). The neural arch shows a fracture surface in the area of contact with the centrum. This fracture may reflect osteological maturity (Horner and Currie, 1994), as it occurs in other reptile groups, but it cannot be definitely stated without an osteohistological analysis (Irmis, 2007). Its size (lateromedial width: $91.44 \mathrm{~mm}$, anteroposterior length: $66.97 \mathrm{~mm}$, and dorsoventral height: $57.73 \mathrm{~mm}$ ) is similar to the dorsal vertebrae of Macrogryphosaurus, indicating it belongs to an ornithopod distinct from smaller taxa such as Gasparinisaura, Notohypsilophodon, Anabisetia or Trinisaura (Fig. 3; Coria and Salgado, 1996b; Martínez, 1998; Coria and Calvo, 2002; Calvo et al., 2007; Coria et al., 2013).

MAU-Pv-PH-458 has preserved the base of the neural spine, both transverse processes, which are almost complete, both prezygapophyses, which are complete, and the base of both postzygapophyses. The neural spine is narrow lateromedially and wide anteroposteriorly. The transverse processes are slightly dorsoposteriorly directed and wider anteroposteriorly than dorsoventrally, as in other ornithopods (Norman et al., 2004). On the ventral side, there is a strong lateromedial ridge with two concave areas, anterior and posterior to the base of the ridge. The anterior concave area is wider and deeper than the posterior one. The prezygapophyses are longer anteroposteriorly than wide lateromedially, with a quadrangular articular face. They face inwardly, upwardly, and a little forwardly. The neural spine does not reach the base of this channel, staying up to the anterior border of the transverse processes. In dorsal view, close to the base of the prezygapophysis, there is a shallow concavity. The base of the postzygapophysis is separated by a deep and closed channel. Their articular surfaces are broken but were apparently laterally inclined. The area under the postzygapophysis is broken, in view of which the existence of a hyposphene could not be corroborated in MAU-Pv-PH-458. This area shows the continuation of the deep channel that separates the base of the two postzygapophyses. This channel is very similar to that observed in the 13th dorsal vertebra of Macrogryphosaurus (Calvo et al., 2007; Fig. 3F and G). The neural arch is more circular and wider that in Macrogryphosaurus (Fig. 3D and E).

\section{Discussion and paleobiogeography}

The morphology of MAU-Pv-PH-458 is similar to that observed in other dorsal neural arches of ornithopod dinosaurs (Norman et al., 2004). Due to its fragmentary condition and the fact that the dorsal vertebrae of ornithopods do not have autapomorphies that permit a specific taxonomic assignment, MAU-Pv-PH-458 is referred to an indeterminate ornithopod. According to its size and compared with the ornithopod record from Argentina plus Antarctica, MAU-Pv-PH-458 belongs to an indeterminate ornithopod of almost 6 meter long, similar to Macrogryphosaurus and slightly larger than Talenkauen and Morrosaurus (Novas et al., 2004; Calvo et al., 2007; Rozadilla et al., 2016). 


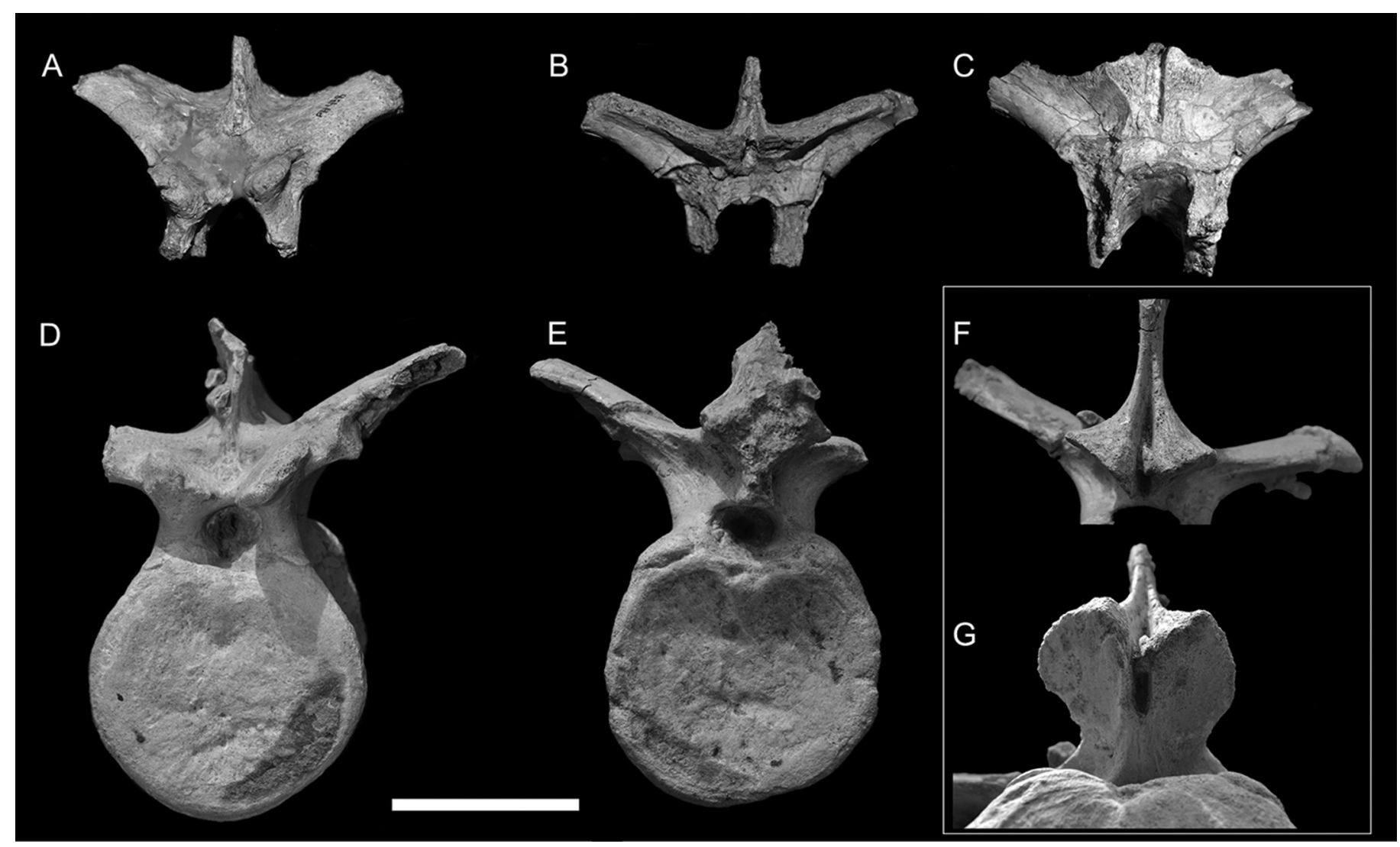

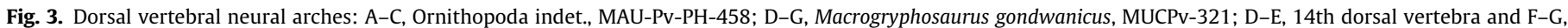
detail of 13th dorsal vertebra. A and D in anterior view; B, E and $\mathrm{F}$ in posterior view, and $\mathrm{C}$ and $\mathrm{G}$ in ventral view. Scale: $5 \mathrm{~cm}$.

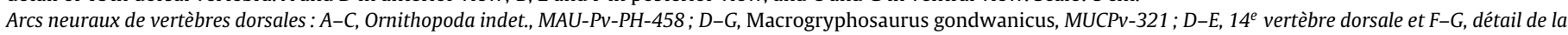
$13^{e}$ vertèbre dorsale. A et $D$ en vue antérieure; $B$, E et $F$ en vue postérieure, et $C$ et $G$ en vue ventrale.

MAU-Pv-PH-458 is part of a rich South American ornithopod record from Cenomanian to the Maastrichtian. The remains have assignment taxonomic to high level and specific level with seven species described. This record is distributed along all Patagonian provinces plus Antarctica having at least one species for province (see Table 1). In the Coniacian-Santonian interval, the highest diversity of ornithopod remains is observed in the Neuquén province. MAU-Pv-PH-458 coincides stratigraphically and geographically with Macrogryphosaurus (also from the Neuquén Province) and only in time interval with Gasparinisaura and Notohypsilophodon (from Río Negro and Chubut provinces, respectively). Outside South America, MAU-Pv-PH-458 is contemporary with the two Asian taxa Haya griva Makovicky et al. (2011) and Koreanosaurus boseongensis Huh et al. (2011) and the European taxon Rhabdodon Matheron, 1868-1869. According to Boyd (2015), these Asian taxa belong to clade Parkosauridae, like the Argentinian clade Elasmaria (Macrogryphosaurus, Notohypsilophodon and Talenkauen). According to this same author, South American ornithopod taxa were product of two migratory pulses: a first one from Australia (possibly via Antarctica) and a second one from Asia through North America. The diversification of the taxa of the second migratory pulse gave rise to the clade Elasmaria and also probably to the ornithopods located in northern Patagonia, from which MAU-PV-PH-458 is originated.

\section{Conclusions}

The discovery of MAU-Pv-PH-458 increases the knowledge about temporal and spatial distribution of medium/large-sized ornithopods in the Upper Cretaceous of Argentina plus Antarctica (see Table 1). The fossil record indicates that the Upper Cretaceous ornithopods were widely distributed throughout Argentina and Antarctica, and that they formed a rich biota.

Finally, MAU-Pv-PH-458 adds a new record of Ornithopoda to the Plottier Formation, up to now consisting only in a pedal ungueal phalanx from El Anfiteatro area (Río Negro province). On this context, MAU-Pv-PH-458 is the northernmost record of a South American ornithopod, the second record of an ornithopod in the Plottier Formation, and the first of this unit in the Neuquén province. Thus, the known distribution range of this clade of dinosaurs during the Coniacian-early Santonian is extended. Future study of this formation in this area and the acquisition of new material would be of great interest to the poor knowledge of the ornithopods of this period, and will improve our understanding of this fauna in Argentina.

\section{Disclosure of interest}

The authors declare that they have no competing interest.

\section{Acknowledgements}

Financial support has been provided by the municipality of Rincón de los Sauces, Neuquén Province, Argentina (LSF), Agencia Nacional de Promoción Científica y Técnica (PICT 20111989; AHM) and the Spanish Ministerio de Ciencia e Innovación (CGL2014-53548-P; PCC). The excavations and restoration of the fossils have been supported by the municipality of Rincón de los Sauces (Neuquén, Argentina). The authors would like to thank to S. de Valais (IIPG-UNRN) and Xabier Pereda-Suberbiola (UPV/EHU) 
provided valuable comments on an early stage of this research. We acknowledge J.M. Gasca (University of Zaragoza, Spain) and an anonymous reviewer for their comments on the manuscript.

\section{References}

Ameghino, F. 1899. Nota preliminar sobre el Loncosaurus argentinus, un representante de la familia Megalosauridae de la República Argentina. Anales de la Sociedad Científica Argentina 49, 61-62.

Boyd, C.A., 2015. The systematic relationships and biogeographic history of ornithischian dinosaurs. Peer J 3, e1523, http://dx.doi.org/10.7717/peerj.1523.

Calvo, J.O., Porfiri, J.D., 2003. More evidence of basal iguanodontians from Barreales Lake (Upper Turonian-Lower Coniacian), Neuquén, Patagonia, Argentina. Ameghiniana Suplemento Resúmenes 40, 53R.

Calvo, J.O., Porfiri, J.D., Novas, F.E., 2007. Discovery of a new ornithopod dinosaur from the Portezuelo Formation (Upper Cretaceous), Neuquén, Patagonia, Argentina. Arquivos do Museu Nacional, Rio de Janeiro 65, 471-483.

Canudo, J.I., Filippi, L., Salgado, L., Garrido, A., Cerda, I., García, R., Otero, A., 2009. Dientes de terópodos asociados con una carcasa de un saurópodo en el Cretácico Superior (Formación Plottier) de Rincón de los Sauces (Patagonia, Argentina). In: Actas de las IV Jornadas Internacionales sobre Paleontología de Dinosaurios y su Entorno, Salas de los Infantes, Burgos, pp. 321-330.

Canudo, J.I., Salgado, L., Garrido, A.C., Carballido, J., 2013. Primera evidencia de dinosaurios ornitópodos en la base de la Formación Huincul (Cenomaniense Superior-Turoniense, Cuenca Neuquina, Argentina). Geogaceta 53, 9-12.

Coria, R.A., 1999. Ornithopod dinosaurs from the Neuquén Group, Patagonia, Argentina; phylogeny and biostratigraphy. In: Tomida, Y., Rich, T.H., VickersRich, P. (Eds.), Proceedings of the Second Gondwanan Dinosaur Symposium. National Science Museum Monographs 15, 47-60.

Coria, R.A., Calvo, J.O., 2002. A new iguanodontian ornithopod from Neuquén Basin, Patagonia, Argentina. Journal of Vertebrate Paleontology 22, 503-509.

Coria, R.A., Cambiaso, A.V., 2007. Ornithischia. In: Gasparini, Z., Salgado, L., Coria, R.A. (Eds.), Patagonian Mesozoic Reptiles. Indiana University Press, pp. 167-187.

Coria, R.A., Salgado, L., 1996a. "Loncosaurus argentinus" Ameghino, 1899 (Ornithischia, Ornithopoda): a revised description with comments on its phylogenetic relationships. Ameghiniana 3, 373-376.

Coria, R.A., Salgado, L., 1996b. A basal iguanodontian (Ornithischia: Ornithopoda) from the Late Cretaceous of South America. Journal of Vertebrate Paleontology $16,445-457$

Coria, R.A., Cambiaso, A.V., Salgado, L., 2007. New records of basal ornithopod dinosaurs in the Cretaceous of North Patagonia. Ameghiniana 44, 473-477.

Coria, R.A., Moly, J.J., Reguero, M., Santillana, S., Marenssi, S., 2013. A new ornithopod (Dinosauria; Ornithischia) from Antarctica. Cretaceous Research 41, 186-193.

Coria, R.A., Salgado, L., Currie, P.J., Paulina Carabajal, A., Arcucci, A.B., 2004. Nuevos registros de iguanodontes basales en el Cretácico de norpatagonia. Ameghiniana Suplemento Resúmenes 41, 42R.

Dingus, L., Clarke, J., Scott, G.R., Swisher, C.C., Chiappe, L.M., Coria, R.A., 2000. Stratigraphy and Magnetostratigraphic/Faunal Constraints for the Age of Sauropod Embryo-Bearing Rocks in the Neuquén Group (Late Cretaceous, Neuquén Province, Argentina). American Museum Novitates 3290, 1-11.

Filippi, L.S., Canudo, J.I., Salgado, L., Garrido, A.C., García, R., Cerda, I., Otero, A., 2011. A new sauropod from the Plottier Formation of Patagonia (Argentina). Geologica Acta 9, 1-12.

Filippi, L.S., Martinelli, A.G., Garrido, A.C., 2013. Registro de un dinosaurio Aeolosaurini (Sauropoda, Titanosauria) en el Cretácico Superior (Formación Plottier) del Norte de la Provincia de Neuquén, Argentina, y comentarios sobre los Aeolosaurini sudamericanos. Revista Brasilera de Paleontología 16, 147-156.

Garrido, A.C., 2010. Estratigrafía del Grupo Neuquén, cretácico Superior de la Cuenca Neuquina (Argentina): nueva propuesta de ordenamiento litoestratigráfico. Revista del Museo Argentino de Ciencias Naturales 12, 121-177.
Horner, J.R., Currie, P.J., 1994. Embryonic and neonatal morphology and ontogeny of a new species of Hypacrosaurus (Ornithischia, Lambeosauridae) from Montana and Alberta. In: Carpenter, K., Hirsch, K.F., Horner, J.R. (Eds.), Dinosaur Eggs and Babies. Cambridge University Press, pp. 312-336.

Von Huene, F., 1929. Los Saurisquios y Ornitisquios del Cretaceo Argentino. Anales del Museo de La Plata 3, 196.

Hooker, J.J., Milner, A.C., Sequeira, S.E.K., 1991. An ornithopod dinosaur from the Late Cretaceous of West Antarctica. Antarctic Science 3, 331-332.

Huh, M., Lee, D.-G., Kim, J.-K., Lim, J.-D., 2011. A new basal ornithopod dinosaur from the Upper Cretaceous of South Korea. Neues Jahrbuch für Geologie und Paläontologie, Monatshefte 259, 1-24.

Ibiricu, L.M., Martínez, R.D., Lamanna, M.C., Casal, G.A., Luna, M., Harris, J.D., Lacovara, K.J., 2010. A medium-sized ornithopod (Dinosauria: Ornithischia) from the Upper Cretaceous Bajo Barreal Formtion of Lago Colhué Huapi, southern Chubut Province, Argentina. Annals of Carnegie Museum 79, 39-50.

Ibiricu, L.M., Martínez, R.D., Luna, M., Casal, G.A., 2014. A reappraisal of Notohypshilophodon comodorensis (Ornithischia: Ornithopoda) from the Late Cretaceous of Patagonia, Argentina. Zootaxa 3786, 401-422.

Irmis, R.B., 2007. Axial skeleton ontogeny in the Parasuchia (Archosauria: Pseudosuchia) and its implications for ontogenetic determination in archosaurs. Journal of Vertebrate Paleontology 27, 350-361.

Lamanna, M., Luna, M., Martinez, R., Ibiricu, L., Sciutto, J.C., 2003. New crocodyliform and dinosaur discoveries from the Upper Cretaceous (Campanian?Maastrichtian) upper member of the Bajo Barreal Formation, Southern Chubut province, Argentina. Abstracts of papers. Sixty-third annual meeting Society of Vertebrate Paleontology, Science Museum of Minnesota 23, Supplement to Number 3. Journal of Vertebrate Paleontology, 70A.

Martínez, R.D., 1998. Notohypsilophodon comodorensis, gen. et sp. nov., un Hypsilophodontidae (Ornithischia: Ornithopoda) del Cretacico Superior de Chubut, Patagonia central, Argentina. Acta Geologica Leopoldensia 21 (46/47), 119-135.

Makovicky, P.J., Kilbourne, B.M., Sadleir, R.W., Norell, M.A., 2011. A new basal ornithopod (Dinosauria, Ornithischia) from the Late Cretaceous of Mongolia. Journal of Vertebrate Paleontology 31, 626-640.

Matheron, P., 1868-1869. Note sur les reptiles des dépôts fluviolacustres crétacés du bassin à lignite de Fuveau. Bulletin de la Société Géologique de France série 226, 781-795.

Miall, A.D., 1996. The Geology of Fluvial Deposits. Sedimentary Facies, Basin Analysis, and Petroleum Geology. Springer, New York.

Molnar, R., 1980. Australian Late Mesozoic terrestrial tetrapods: some implications. Mémoires de la Société Géologique de France 139, 131-143.

Norman, D.B., Sues, H.-D., Witmer, L.M., Coria, R.A., 2004. Basal Ornithopoda. In: Weishampel, D.B., Dodson, P., Osmólska, H. (Eds.), The Dinosauria. University of California Press, pp. 393-412.

Novas, F.E., Cambiaso, A.V., Ambrosio, A., 2004. A new basal iguanodontian (Dinosauria, Ornithischia) from the Upper Cretaceous of Patagonia. Ameghiniana $41,75-85$.

Porfiri, J.D., Calvo, J.O., 2002. A new record of an ornithopod dinosaur from the Upper Cretaceous of Neuquén, Patagonia, Argentina. In: Primer Congreso Latinoamericano de Paleontología de Vertebrados, Santiago de Chile, Resúmenes, p. 45.

Rozadilla, S., Agnolin, F.L., Novas, F.E., Aranciaga Rolando, A.M., Motta, M.J., Lirio, J.M., Isasi, M.P., 2016. A new ornithopod (Dinosauria, Ornithischia) from the Upper Cretaceous of Antarctica and its palaeobiogeographical implications. Cretaceous Research 57, 311-324.

Salgado, L., Coria, R.A., Heredia, S.E., 1997. New materials of Gasparinisaura cincosaltensis (Ornithischia, Ornithopoda) from the Upper Cretaceous of Argentina. Journal of Paleontology 71, 933-940.

Salgado, L., Canudo, J.I., Garrido, A.C., Ruiz-Omeñaca, J.I., García, R.A., de la Fuente, M.S., Barco, J.L., Bollati, R., 2009. Upper Cretaceous vertebrates from "El Anfiteatro" (Río Negro, Patagonia, Argentina). Cretaceous Research 30, $767-784$ 